\title{
The Correlation between Wind Direction and Wind Speed with The Landing Accuracy Result on Paragliding Athletes
}

\author{
Sahri Sahri ${ }^{1}$, Nanang Indardi ${ }^{2}$, Nur Amin $^{3}$ \\ \{sahri@mail.unnes.ac.id ${ }^{1}$, nanangindardi@mail.unnes.ac.id ${ }^{2}$, nuramin@unw.ac.id ${ }^{3}$ \} \\ Universitas Negeri Semarang, Semarang, Indonesia ${ }^{12}$ \\ Universitas Ngudi Waluyo, Semarang, Indonesia ${ }^{3}$
}

\begin{abstract}
Paragliding is one of the extremes sports. One of the contested categories is landing accuracy. The purpose of the research is to know the relationship between wind direction and wind speed due to the result of the landing accuracy of athletes. This type of research includes crossectional by using a total sampling technique in 61 paragliding athletes. Determinants of wind direction and wind speed measurements conducted when the athletes made the landing. The measurement of landing accuracy measures at the first foot on the ground. The results show that the wind direction was associated with the result of landing accuracy $(\mathrm{p}=0,02)$. While the wind speed is not related to landing accuracy $(\mathrm{p}=0,12)$, it concluded that the landing accuracy result could influence by wind direction.
\end{abstract}

Keywords: wind direction, wind speed, landing accuracy, paragliding.

\section{Introduction}

Paragliding is the sport of free-flying using a parachute by starting to take off on foot. Paragliding by some people occupied with the aim of recreation or achievement. The association of this sport in Indonesia is FASI (Federation of Aero Sport Indonesia). Paragliding takes off from a hillside or mountain and takes advantage of the wind. The wind used as a lifting power, which then causes the parachute flies high in the air. The flight mechanism consists of two kinds, namely, dynamic lift, that is the rising wind that hits the slope and thermal lift that is the rising wind caused by thermal [1]. By making use of both sources, the pilot can fly high and reach great distances. The most interesting is that all applied without using a machine, only solely making use of the wind [2].

Some contested categories in paragliding accuracy of landing, cross the country open distance, and race to the goal [3]. One additional contested category in Indonesia is tandem accuracy, which is flying carrying passengers and landing at a determined point. In recent years, contestant pilots have increased significantly. This can be seen from the number of participants participating in paragliding championships held in all regions of Indonesia on landing accuracy numbers. 
In the landing accuracy category, several factors can affect the results. One of them is the wind factor. When flying, athletes make use of the direction and speed of the wind to regulate the high and low position of the fly and the speed of the parachute. Not only the direction and speed of the wind, the strength or magnitude of the wind will also affect the athlete's ability to raise or lower his flight position. Even so, if an athlete makes a landing at high wind speeds, there is a considerable risk of being dragged when landing near the point [4]. In the championship of landing accuracy number, some accidents often occur, one of the accidents is when the athlete makes a landing [5,6,7]. This happens due to many factors, such the athletes to impose to make lower altitude, landing not conformed to the direction of the wind (crosswind/tailwind), wind speed, athlete's concentration, etc.

\section{$2 \quad$ Method}

This research is the correlational descriptive research using total sampling techniques of 61 paragliding athletes. Athletes fly using the main parachute that suits to the athlete's weight capacity, spare parachute, harness, helmet, communication radio, and shoes. All flights supervised by a safety officer who is responsible for activities. Take off is regulated by launch marshal who regulates flight distance, recommends wind speed (0-15 knots), and proper wind direction (direct wind towards the crosswind hill for senior athletes) and check flight equipment [8,9]. Landing is assessed by the judge, who measures the results of landing accuracy and determine the athlete's fall (get a maximum value of $500 \mathrm{~cm}$ ) or not. The instruments and measuring methods used in this study are:

\subsection{Measurement of Wind Speed and Determination of Wind Direction}

The tool used is a windmeter. Measurements are made at several points around the landing place just before the athlete makes a landing. The unit of wind speed is $\mathrm{m} / \mathrm{s}$ or knots. The tool used is a windsock. Determination of wind direction applied by placing windsock at several points around the landing site and wind direction is determined just before the athlete makes a landing. The wind direction categories used in this study are: East, southeast, south, southwest, west, northwest, north, and northeast. As for the term wind direction flight can be categorized in headwind, crosswind and tailwind $[10,11]$.

\subsection{Measurement of Landing Accuracy Result}

The tool used is a dead center disc with a digital system whose results displayed on the screen (measuring radius $0-22 \mathrm{~cm}$ ) and gauge (measuring radius $22 \mathrm{~cm}-499 \mathrm{~cm}$ ) conducted by a certified judge. Measurements took when the athlete landed, and what measured is the first stepping foot touching the ground. If an athlete lands by doing fall (landing on the landing area or harness hits the ground), the athlete will get a maximum score of $500 \mathrm{~cm}$ [12]. 


\subsection{Data Analysis}

Secondary data and data obtained from the results of measurements of wind speed, determination of wind direction, and landing accuracy were analyzed univariate to describe primary data to determine the frequency of all variables and facilitate further analysis. A bivariate analysis then performed using Spearman's correlation test, which aims to determine the correlation between each variable. The analysis results are said to be related if the test results show a significance value of $p<0.05$ and said to be unrelated if the test results show a significance value of $p>0.05$.[13]

\section{$3 \quad$ Result and Discussion}

The subjects in this study were paragliding athletes with an age range of 16-45 years, with an average age of 29 years. The age range far adrift is due to there is no age limit to conduct paragliding. Unlike some sports in general, the requirement to participate in paragliding championships is for the athlete to pass the exam to get a pilot license. The average respondent in the study was a licensed PL-1 (Pilot License). In paragliding, license categories qualify into PL-1, PL-2, PL-3, and for commercial pilots (master tandem), namely T-1, T2, and T-3. However, at the time of the championship by the safety officer, the participant category was distinguished between juniors (PL-1) who considered to be able to master the basic paragliding and senior techniques (PL-2 AND PL-3) who had mastered advanced techniques (mid and high techniques). At the time of research, wind direction at the flight location tends to blow from the southeast with an average wind speed of 6-10 knots. A general description of the characteristics of research subjects can be seen in table 1 .

Table 1. Overview of Characteristics of Research Subjects

\begin{tabular}{|c|c|c|c|c|c|c|c|c|c|}
\hline \multirow{3}{*}{ Characteristic } & \multicolumn{6}{|c|}{$\begin{array}{l}\text { Landing Accuracy Results } \\
(4.01+176.14)(\mathrm{N}=61)\end{array}$} & \multirow{2}{*}{\multicolumn{2}{|c|}{ Amount }} & \multirow{3}{*}{ p-value } \\
\hline & \multicolumn{2}{|c|}{$0-22$} & \multicolumn{2}{|c|}{$23-499$} & \multicolumn{2}{|c|}{500} & & & \\
\hline & n & $\%$ & n & $\%$ & $\mathbf{N}$ & $\%$ & $\mathrm{n}$ & $\%$ & \\
\hline \multicolumn{10}{|l|}{ Age $(29.06 \pm 9.09)$} \\
\hline$<20$ & 1 & 1.6 & 2 & 6.6 & 9 & 14.8 & 12 & 19.7 & \multirow{3}{*}{0.37} \\
\hline $20-35$ & 4 & 6.6 & 8 & 13.1 & 19 & 31.1 & 31 & 50.8 & \\
\hline$>35$ & 0 & 0 & 3 & 4.9 & 15 & 24.6 & 18 & 29.5 & \\
\hline \multicolumn{10}{|l|}{ Gender } \\
\hline Male & 5 & 8.2 & 12 & 19.7 & 38 & 62.3 & 55 & 90.2 & \multirow[t]{2}{*}{0.43} \\
\hline Female & 0 & 0 & 1 & 1.6 & 5 & 8.2 & 6 & 9.8 & \\
\hline \multicolumn{10}{|l|}{ License } \\
\hline Juniority & 2 & 3.3 & 9 & 14.8 & 32 & 52.5 & 43 & 70.5 & \multirow[t]{2}{*}{0.23} \\
\hline Seniority & 3 & 4.9 & 4 & 6.6 & 11 & 18 & 18 & 29.5 & \\
\hline \multicolumn{10}{|l|}{ Wind Direction } \\
\hline East & 3 & 4.9 & 4 & 6.6 & 8 & 13.1 & 15 & 24.6 & \multirow{4}{*}{$0.02 *$} \\
\hline Southeast & 2 & 3.3 & 9 & 14.8 & 28 & 45.9 & 39 & 63.9 & \\
\hline South & 0 & 0 & 0 & 0 & 2 & 3.3 & 2 & 3.3 & \\
\hline Southwest & 0 & 0 & 0 & 0 & 0 & 0 & 0 & 0 & \\
\hline
\end{tabular}




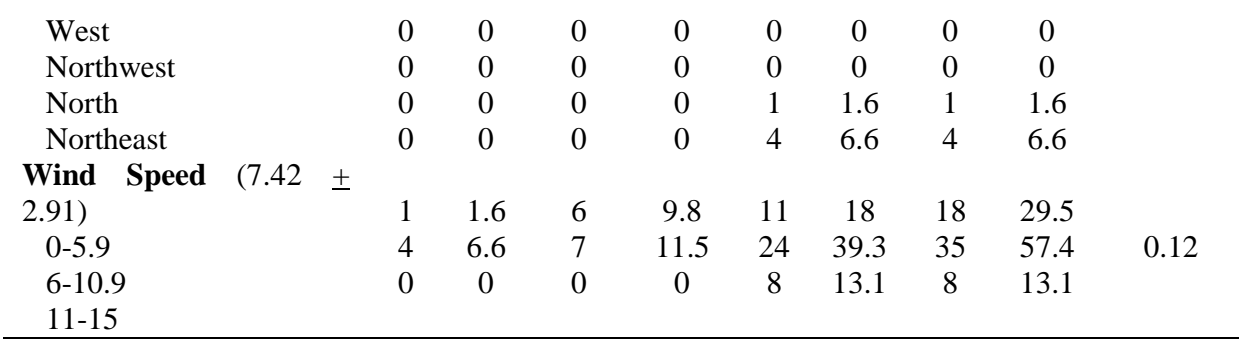

Correlation test using the Spearman's Test

Significant at the 0.05 level indicated by notation *

\subsection{The Correlation between Wind Speed with Landing Accuracy}

Table 1 shows that there is no significant the correlation between wind speed and the accuracy of landing results $(\mathrm{p}=0.12)$. This was because before the subjects did flight, it determines in which wind speed some are allowed to do the flight, that recommended by launch marshal. It means when taking off and landing, the subject was in a relatively safe wind speed condition and would be easy to control the parachute [13]. The recommended wind speed for flight is $0-15$ knots. 8 Wind speed is one of the factors that must be considered by safety officers and launch marshal in providing flight recommendations due to frequent accidents during take-off or landing caused by wind speed [14]. So that athletes can avoid the risk of flight accidents [15].

\subsection{The Correlation between Wind Direction with Landing Accuracy}

Table 1 shows a significant between wind direction and landing accuracy $(\mathrm{p}=$ 0.02). The ability of subjects to read the direction of the wind and direct the parachute in the same direction of the wind, which could make the parachute easily controlled during landing, could help them get good landing accuracy. Indonesia has two global winds, namely the east monsoon in April - September and the west monsoon in October - March [16]. Which are used as the basis by aerospace sports activists to determine the feasibility of a training ground $[17,18]$. Beside chief judge who always reports the condition of the wind when it changes, athletes are also required to be able to read the direction of the wind by looking at the windsock when flying [19]. So that athletes can make decisions precisely from which direction they should land and can minimize accidents due to hard landing.

\section{Conclusion}

It can conclude that the wind direction influenced landing accuracy; otherwise, the wind speed did not influence the accuracy of landing accuracy. The ability of athletes to read wind direction during landing is a crucial factor in getting good landing accuracy results. Suggestions for the future need to research the physical condition of athletes that support in getting good landing accuracy results. 


\section{Acknowledgment}

The researcher is thankful to the paragliding athletes in Central Java, Indonesia, who had been willing to become research subjects. Also, thanks to the Central Java paragliding trainer and management team who have given research permission. Beholden to Enumerators and judges who have assisted the research process. Moreover, Universitas Negeri Semarang that have helped with funding so that this research can run well.

\section{References}

[1] Panayiotis, K. Guide to Paragliding. Glyfada Athens Greece: Pocket Aviation ${ }^{\mathrm{TM}}$; 2012.

[2] Rzucidlo A. Thermals Map - Assist Flight System. International Book Series "Information Science and Computing. 2009; 13: 85-88.

[3] Whittall N. Paragliding The Complete Guide Revised \& Update. New York: The Lions Press; 1995.

[4] Vargas M, D.Wang. Paragliding Site Selection an Development - The Basic. Taiwan: USHPA; 2009.

[5] Schulze W, Richter J, Schulze B, Esenwein SA, Buttner-Janz K. Injury Prophylaxis in Paragliding. Br J Sports Med. 2002; 36: 365-369.

[6] Feletti F, Goin J. Accidents and Injuries Related to Powered Paragliding: A CrossSectional Study. BMJ Open. 2014; 4: 1-7.

[7] Atreya A, Kanchan T. Analysis of Paragliding Accident - A Preliminary Investigation from Nepal. Nepal Med Coll J. 2016; 18(1-2): 5-8.

[8] Pagen D. Understanding The Sky. Illustrated Ed. United States of America: Sport Aviation Pubns; 1992.

[9] Guoxi H, Shuguang Z. Research on Assessment Indicates of Safety and Comfort for Flight in Wind Fields. International Symposium on Aircraft Airworthiness. Elsevier Ltd. 2011; 17: 104-116.

[10] IVAO. Crosswind and Headwind Calculation. International Virtual Aviation Organisation. https://mediawiki.ivao.aero/index.php?title=Crosswind_and_Headwind_calculation

[11] Van Es GWH, Karwal AK. Safety of Tailwind Operations. Netherland: National Aerospace Laboratory; 2001.

[12] FAI. Section 7C-Class O Paragliding Accuracy. Switzerland: Federation Aeronautaque Internationale; 2019.

[13] Uyanto SS. Pedoman Analisis Data Dengan SPSS Edisi 3. Yogyakarta: Graha Ilmu; 2009.

[14] Vargas M. Introduction A Training Manual and Study Guide for Beginner and Notice Level Pilot. Taiwan: USHA; 2008.

[15] Scott D, Lemieux C. Weather and Climate Information for Tourism. Procedia Environmental Sciences I; 31 August-4 September; Geneva: Elsevier; 2010. 146-183.

[16] Dia HP, Suparman S, Widhiyanuriyawan D. Pemetaan Potensi Energi Angin di Perairan Indonesia Berdasarkan Data Satelit QuikScat dan WindSat. Jurnal Rekayasa Mesin. 2016; 7(2): 95-101.

[17] Falavarjani NG. Wind to Select The Recreation Flying Site. International J. of Geograph. and Geo. 2015; 4(3): 57-67. 
[18] Fatkhuroyan, Wati T, Kamid A. Karakteristik Angin dan Take Off dan Landing Pesawat. Prosiding Seminar Nasional Fisika; 29 Juni; Jakarta. ResearchGate; 2018. 8591.

[19] Jovanovic V, Njegus A. The Application of GIS and Its Components in Tourism. Yugoslav J. of Operations Research. 2008; 18: 261-272. 